\title{
OPEN Development and validation of a multiplex qPCR assay for detection and relative quantification of HPV16 and HPV18 $E 6$ and $E 7$ oncogenes
}

\author{
Alexia Bordigoni ${ }^{1,3}$, Anne Motte $^{1,3}$, Hervé Tissot-Dupont ${ }^{1,3}$, Philippe Colson ${ }^{1,3}$ \& \\ Christelle Desnues ${ }^{1,2,3 凶}$
}

Human papillomaviruses (HPV) play a key role in promoting human anogenital cancers. Current high-risk HPV screening or diagnosis tests involve cytological or molecular techniques mostly based on qualitative HPV DNA detection. Here, we describe the development of a rapid quantitative polymerase chain reaction (qPCR) detection test of HPV16 and HPV18 oncogenes (E6 and E7) normalized on human gene encoding GAPDH. Optimized qPCR parameters were defined, and analytical specificities were validated. The limit of detection was $10^{1}$ for all genes tested. Assay performances were evaluated on clinical samples $(n=96)$. Concordance between the Xpert HPV assay and the triplex assay developed here was $93.44 \%$ for HPV16 and $73.58 \%$ for HPV18. HPV co-infections were detected in 15 samples. The systems developed in the present study can be used in complement to traditional HPV tests for specifically validating the presence of HPV16 and/or HPV18. It can also be used for the follow-up of patients with confirmed infection and at risk of developing lesions, through the quantification of $E 6$ and $E 7$ oncogene expression (mRNA) normalized on the GAPDH expression levels.

Human papillomaviruses (HPVs) are non-enveloped icosahedral particles with a size of 50-60 nm diameter ${ }^{1}$. These circular double-stranded DNA viruses have a genome size close to 8 kilobases that includes open reading frames (ORF) encoding E1-E7 proteins involved in the transactivation of transcription, transformation, replication and viral adaptation into the host cells ${ }^{2,3}$. HPVs are involved in the development of cutaneous or genital warts (or condyloma) and of benign or malignant tumors ${ }^{4}$. Currently, more than 200 HPV types (https://pave. niaid.nih.gov/) are described and categorized in two groups, namely low-risk (LR) and high-risk (HR) HPVs according to their capacity to promote cell transformation that leads to cancer development. According to the Center for Disease Control and prevention, more than $90 \%$ of anal and cervical cancers and 50\% of vaginal, vulvar, and penile cancers are due to HPVs ${ }^{5}$. HPV 16 and 18 are frequently associated with anal cancer (87\%), cervical, vulvar or penile cancer (70\%), vaginal cancer (64\%), but also head and neck cancer $(85 \%)^{6}$.

HPVs infect basal epithelial cells of the skin (cutaneotropic) and of the mucosa of the anogenital and the oropharyngeal tracts (mucosotropic). Cancerous lesions are due to persistence of HPVs that are not cleared in the epithelium by the human immune system ${ }^{4,7,8}$. Indeed, a productive viral replication is associated with a lowgrade intraepithelial lesion ${ }^{9}$. The progression to precancerous and cancerous lesion up to cervical intraepithelial neoplasia and eventually to cervical cancer occurs with a persistent HR-HPV infection and the integration of the HPV genome into the host chromosome mediated by host DNA replication and recombination ${ }^{10}$, the loss or disruption of $\mathrm{E} 2$ protein and the subsequent upregulation of $E 6$ and $E 7$ oncogenes expressions ${ }^{11}$. These oncoproteins are involved in malignant transformation by altering cell cycle regulation and telomere maintenance via the telomerase activation and the degradation of the tumor suppressors p53 by E6 and retinoblastoma protein

\footnotetext{
${ }^{1}$ Aix-Marseille Université, IRD 198, Assistance-Publique des Hôpitaux de Marseille, UMR Microbes, Evolution, Phylogeny and Infections (MEPHI), Marseille, France. ${ }^{2}$ Aix-Marseille Université, Université de Toulon, CNRS, IRD, Mediterranean Institute of Oceanography (MIO), MEB, UM 110, 163 avenue de Luminy, Case 901, Bâtiment OCEANOMED-Méditerranée, 13288 Marseille Cedex 09, France. ${ }^{3} \mathrm{HHU}$ Méditerranée Infection, Marseille, France. ${ }^{\square}$ email: christelle.desnues@univ-amu.fr
} 


\begin{tabular}{|c|c|c|c|c|c|c|}
\hline \multirow[b]{2}{*}{ Target } & \multirow[b]{2}{*}{ Oligonucleotide } & \multirow[b]{2}{*}{ Sequence $5^{\prime}-3^{\prime}$} & \multirow[b]{2}{*}{ Amplicon length (bp) } & \multirow[b]{2}{*}{ Reference } & \multicolumn{2}{|c|}{$\begin{array}{l}\text { Oligonucleotide } \\
\text { position on reference } \\
\text { genome }\end{array}$} \\
\hline & & & & & From & To \\
\hline \multicolumn{7}{|l|}{ HPV 16} \\
\hline \multirow{3}{*}{ E6 gene } & Primer E6 F & 5'-AATGTTTCAGGACCCACAGG-3' & \multirow{3}{*}{$107 \mathrm{bp}$} & \multirow{6}{*}{$\begin{array}{l}\text { This study on HPV16 reference } \\
\text { genome NC_001526.4 NCBI }\end{array}$} & 7145 & 7164 \\
\hline & Primer E6 R & 5'-GTTGCTTGCAGTACACACATTC-3' & & & 7230 & 7251 \\
\hline & Probe E6 & 5'-ACCACAGTTATGCACAGAGCTGCA-3' & & & 7181 & 7204 \\
\hline \multirow{3}{*}{ E7 gene } & Primer E7 F & 5'-TCAGAGGAGGAGGATGAAATAGA-3' & \multirow{3}{*}{$111 \mathrm{bp}$} & & 7697 & 7719 \\
\hline & Primer E7 R & 5'-GCACAACCGAAGCGTAGA-3' & & & 7790 & 7807 \\
\hline & Probe E7 & 5'-AGAACCGGACAGAGCCCATTACAA-3' & & & 7738 & 7761 \\
\hline \multicolumn{7}{|l|}{ HPV18 } \\
\hline \multirow{3}{*}{ E6 gene } & Primer E6 F & 5'-ACCCTACAAGCTACCTGATCT-3' & \multirow{3}{*}{$100 \mathrm{pb}$} & \multirow{6}{*}{$\begin{array}{l}\text { This study on HPV18 reference } \\
\text { genome X05015.1 NCBI }\end{array}$} & 134 & 154 \\
\hline & Primer E6 R & 5'-ACCTCTGTAAGTTCCAATACTGTC-3' & & & 212 & 235 \\
\hline & Probe E6 & $\begin{array}{l}\text { 5'-ACGGAACTGAACACTTCACTGCAA } \\
\text { GA-3' }\end{array}$ & & & 159 & 184 \\
\hline \multirow{3}{*}{ E7 gene } & Primer E7 F & 5'-AATTCCGGTTGACCTTCTATGT-3' & \multirow{3}{*}{$102 \mathrm{bp}$} & & 649 & 670 \\
\hline & Primer E7 R & 5'-GGCTGGTAAATGTTGATGAT-3' & & & 723 & 742 \\
\hline & \begin{tabular}{|l|} 
Probe E7 \\
\end{tabular} & 5'-TAAGCGACTCAGAGGAAGAAA-3' & & & 681 & 701 \\
\hline \multirow{3}{*}{ GAPDH } & Primer F & 5'-GGACCTGACCTGCCGTCTAG-3' & \multirow{3}{*}{$99 \mathrm{pb}$} & \multirow{3}{*}{ He et al. $(2017)^{31}$} & & \\
\hline & Primer R & 5'-TAGCCCAGGATGCCCTTGAG-3' & & & & \\
\hline & Probe & 5'-CCTCCGACGCCTGCTTCACCACCT-3' & & & & \\
\hline \multirow{2}{*}{ HPV universal } & MY09 & 5'-GCMCAGGGWCATAATAATGG-3' & \multirow{2}{*}{$450 \mathrm{pb}$} & \multirow{2}{*}{ Cossellu et al. $(2018)^{34}$} & & \\
\hline & MY11 & 5'-CGTCCMARRGGAWACTGATC-3' & & & & \\
\hline
\end{tabular}

Table 1. Primers and probes used in $\mathrm{qPCR}$.

(Rb) by E7 ${ }^{12-14}$. In contrast, LR-HPV oncogenes are less able to interfere with p53 and Rb functions than E6/E7 proteins from HR-types ${ }^{12,15}$.

Nowadays, HR-HPV screening or diagnosis mostly involve cytological techniques that have lowest specificity and sensitivity than molecular techniques ${ }^{16,17}$ but detection of HPV DNA is becoming the first line strategy for cervical cancer in women older than 30 years ${ }^{18-20}$. Commercially available molecular tests are mainly based on the detection of HPV DNA such as Hybrid Capture 2 assay (QIAGEN) ${ }^{21}$, Cervista HPV HR $^{22}$ or HPV 16/18 ${ }^{23}$ (HOLOGIC) Care HPV (QIAGEN) ${ }^{24}$ and Cobas HPV (ROCHE DIAGNOSTICS) ${ }^{25}$, are mainly based on the detection of HPV DNA. These allow detecting the presence of the virus but not evaluating its oncogenic activity. In cervical infections HPV load and its variations have been shown to predict the persistence and progression of HPV infections and the severity of the lesions ${ }^{26,27}$. In 2010, a study showed that mRNA expression levels of E6 and E7 oncogenes were correlated with the severity of cervical lesions ${ }^{28}$, but so far, only few HPV tests target viral mRNAs. They are qualitative (e.g. HPV-Proofer (PRETECT) $)^{29}$ and do not discriminate among HPV types (Aptima HPV Assay (HOLOGIC) $)^{30}$.

The main aim of the present study was to develop a rapid quantitative detection test of HPV16 and HPV18 infections by measuring E6 and E7 oncogene DNA levels normalized by the cellular GAPDH gene level. Multiplex detection of these three genes in a single assay enables reduction in cost, time and labor as compared to separate detection methods. This technique allows for an extra support of traditional HPV tests to validate and quantify specifically the presence of HPV16 and/or HPV18 infection. Once persistent infection is confirmed, it could be used for a follow-up of patients at risk of cervical cancer, by correlating the activation of oncogenes to the severity of the lesions.

\section{Materials and methods}

Primer and probe design. Target sequences of E6 and E7 genes were obtained using the NCBI reference genomes of HPV16 (accession number: NC_001526.4) and HPV18 (accession number: X05015.1). The primers and probes were designed to amplify and detect specifically E6 and E7 oncogenes of HPV16 and HPV18 using PrimerQuest Tool software with default parameters. The specificity of the primers and probes was checked using the online NCBI BLASTn tool against the human genome (https://blast.ncbi.nlm.nih.gov/). Human GAPDH primers were obtained from previous study ${ }^{31}$.

The hydrolysis probes of E6, E7 and GAPDH were labeled on the $5^{\prime}$-end with FAM, VIC and CY5 fluorescent dyes, respectively, and on the $3^{\prime}$-end with a TAMRA compatible quencher for E6 and E7 and BHQ (Black Hole Quencher) for GAPDH.

The sequences of primers and probes, nucleotide positions on HPV16 or HPV18 reference genomes and amplicon lengths are presented in Table 1. Primers and probes were manufactured by EUROGENTEC (Angers, France). 
Positive control synthesis for quantification of gene copy number. HPV DNAs were extracted using a BioRobot EZ1 instrument (QIAGEN) from ATCC HeLa cells for HPV18 (CCL-2) and ATCC SiHa cells for HPV16 (HTB-35) cultured in a MEM medium (GIBCO) supplemented with $10 \%$ fetal bovine serum (GIBCO), 1\% non-essential amino acids 100X (GIBCO), 1\% glutamine 100X (GIBCO), 1\% sodium pyruvate $100 \mathrm{X}$ (GIBCO) at $37^{\circ} \mathrm{C}$ with $5 \% \mathrm{CO}_{2}$. PCRs were performed according to the manufacturer recommendations with AmpliTaq Gold 360 Master Mix kit (THERMOFISCHER) in a $25 \mu \mathrm{L}$ volume containing $12.5 \mu \mathrm{L}$ of $2 \mathrm{X}$ AmpliTaq Gold Mix, $0.5 \mu \mathrm{L}$ of each primer at $10 \mu \mathrm{M}$ and $2 \mu \mathrm{L}$ of template DNA.

Amplicons were produced by standard PCR in a Mastercycler nexus gradient (EPPENDORF) according to the following program: $10 \mathrm{~min}$ at $95^{\circ} \mathrm{C}$; then 40 cycles of $30 \mathrm{~s}$ at $95^{\circ} \mathrm{C}, 30 \mathrm{~s}$ at $60{ }^{\circ} \mathrm{C}$, and $20 \mathrm{~s}$ at $72{ }^{\circ} \mathrm{C}$; and a final extension step of $7 \mathrm{~min}$ at $72{ }^{\circ} \mathrm{C}$. PCR products were analyzed by electrophoresis on a $2 \%$ agarose gel and purified by QIAquick PCR purification (QIAGEN) before being cloned into a PGEM-T easy vector (PROMEGA). The ligation reaction was conducted overnight at $4{ }^{\circ} \mathrm{C}$ according to the manufacturer recommendations. JM109 competent cells (PROMEGA) were transformed by heat shock, before being spread with beads onto Luria-Bertani (LB) (BD DIFCO) agar plates containing $100 \mu \mathrm{g} / \mathrm{ml}$ ampicillin (SIGMA), $0.5 \mathrm{mM}$ isopropyl- $\beta$ D-thiogalactopyranoside (EUROMEDEX) and $80 \mu \mathrm{g} / \mathrm{ml} \mathrm{X-gal} \mathrm{(EUROMEDEX).} \mathrm{Cells} \mathrm{were} \mathrm{incubated} \mathrm{at} 37^{\circ} \mathrm{C}$ for $24 \mathrm{~h}$ or during the weekend at room temperature. Transformants were analyzed by PCR using SP6 ( $5^{\prime}$-TAT TTAGGTGACACTATAG- $3^{\prime}$ ) and T7 primers ( $5^{\prime}$-TAATACGACTCACTATAGGG- $3^{\prime}$ ) according to the following program: $10 \mathrm{~min}$ at $95^{\circ} \mathrm{C}$; then 40 cycles of $30 \mathrm{~s}$ at $95^{\circ} \mathrm{C}, 30 \mathrm{~s}$ at $55^{\circ} \mathrm{C}$, and $20 \mathrm{~s}$ at $72^{\circ} \mathrm{C}$; and a final extension step of $7 \mathrm{~min}$ at $72^{\circ} \mathrm{C}$. Positive $E 6$ and $E 7$ clones for each HPV genotype and GAPDH clones were placed into $7 \mathrm{~mL}$ of LB broth containing $100 \mu \mathrm{g} / \mathrm{mL}$ of ampicillin then incubated overnight at $37^{\circ} \mathrm{C}$ under shaking $(\sim 200 \mathrm{rpm})$. Plasmid DNA was extracted using the Smart Pure Plasmid Kit (EUROGENTEC). Purified plasmids were linearized by digestion with the NcoI restriction enzyme during $15 \mathrm{~min}$ at $37^{\circ} \mathrm{C}$ according to the manufacturer's instructions. Digestion products were run on a $1 \%$ agarose gel and the band was purified using the QIAquick Gel Extraction (QIAGEN). The plasmid concentration was quantified by Nanodrop 2000 (THERMO SCIENTIFIC) for HPV16 and by Multiskan GO (THERMO SCIENTIFIC) for HPV18. The copy numbers (copies/ $\mu \mathrm{L}$ ) were determined with the following formula:

$$
\text { Copy numbers }(\text { copies } / \mu \mathrm{l})=\frac{Q(\mathrm{ng}) \times \mathcal{N}_{A(D a)}}{L(\mathrm{pb}) \times 10^{9} \times M(\mathrm{~g} / \mathrm{mol})}
$$

Plasmid copy numbers were $1.59 \times 10^{10}$ copies $/ \mu \mathrm{L}(G A P D H), 1.44 \times 10^{10}$ copies $/ \mu \mathrm{L}(\mathrm{HPV} 16, \mathrm{E} 6), 9.9 \times 10^{9} \mathrm{cop}$ ies/ $\mu \mathrm{L}$ (HPV16, E7), $1.54 \times 10^{10}$ copies/ $\mu \mathrm{L}(\mathrm{HPV} 18, E 6)$ and $1.58 \times 10^{10} \mathrm{copies} / \mu \mathrm{L}(\mathrm{HPV} 18, E 7)$. Serial dilutions (from $10^{7}$ to $10^{\circ}$ ) of the control plasmids were aliquoted and stored at $-20^{\circ} \mathrm{C}$ until further use. All steps of qPCR development were run with $2 \mu \mathrm{L}$ of plasmid solution.

Multiplex qPCR development. Optimization of HPV16 and HPV18 multiplex was run on a CFX C1000 Touch (BIORAD) to determine the most appropriate annealing temperature $\left(54{ }^{\circ} \mathrm{C}, 56.4{ }^{\circ} \mathrm{C}, 57.8{ }^{\circ} \mathrm{C}, 60{ }^{\circ} \mathrm{C}\right)$, primer concentration $(400 \mathrm{nM}, 600 \mathrm{nM}, 800 \mathrm{nM}, 1000 \mathrm{nM})$ and probe concentration $(50 \mathrm{nM}, 100 \mathrm{nM}, 150 \mathrm{nM}$, $200 \mathrm{nM}$ ) for each gene. According to the manufacturer protocol, qPCRs were performed with a LightCycler 480 Probes Master (ROCHE) kit in $20 \mu \mathrm{L}$ containing primers and probes (at different concentrations listed above), $10 \mu \mathrm{L} 2 \mathrm{X}$ LightCycler 480 probe Master mix, $0.5 \mu \mathrm{L}$ Uracil-DNA Glycosylase (1 U/ $\mu \mathrm{L}$, THERMO SCIENTIFIC) and $2 \mu \mathrm{L}$ of DNA template. Multiplex assays were performed in biological and technical triplicates on $10^{5}$ plasmid copies and using the following steps: $2 \mathrm{~min}$ at $50{ }^{\circ} \mathrm{C} ; 5 \mathrm{~min}$ at $95^{\circ} \mathrm{C} ; 40$ cycles of $10 \mathrm{~s}$ at $95{ }^{\circ} \mathrm{C} ; 20 \mathrm{~s}$ at $\mathrm{Tm}$; and a final $1 \mathrm{~s}$ at $72^{\circ} \mathrm{C}$.

Specificity of the primers. The specificities of the primers-probe couples were tested on each plasmid produced as mentioned above at the concentration of $10^{5}$ copies in a multiplex qPCR by using the optimized parameters on a CFX C1000 Touch (BIORAD). Each run consisted in three steps: 2 min at $50^{\circ} \mathrm{C}, 5 \mathrm{~min}$ at $95^{\circ} \mathrm{C}$, then 40 cycles of $10 \mathrm{~s}$ at $95^{\circ} \mathrm{C}$ and $20 \mathrm{~s}$ at $60^{\circ} \mathrm{C}$.

Efficiency and sensitivity of the PCR systems. PCR efficiency and sensitivity of each primers-probe couple with the optimized conditions were determined using a quantitative standard curve (serial dilution of the positive control plasmid from $10^{7}$ to $10^{0}$ copies). All assays were performed in biological and technical triplicates on a CFX C1000 Touch (BIORAD) with the following program: 2 min at $50{ }^{\circ} \mathrm{C} ; 5 \mathrm{~min}$ at $95^{\circ} \mathrm{C} ; 40$ cycles of $10 \mathrm{~s}$ at $95^{\circ} \mathrm{C}$ and $20 \mathrm{~s}$ at $60^{\circ} \mathrm{C}$. Assays were validated with a slope of regression curve between -3.9 and $-2.9 \mathrm{cycles} /$ $\log _{10}$, a $R^{2}>0.98$ and an efficiency range between 80 and $120 \%{ }^{32}$. The limit of detection (LOD) of the assays was defined as the lowest concentration (target gene copy number per reaction) for which $\geq 95 \%$ of test runs gave positive results.

Multiplex reproducibility. Intra- and inter-assay reproducibility was evaluated based on the cycle threshold $(\mathrm{Ct})$, and the coefficient of variation (CV) of both the biological and the technical replicates, using a concentration of $10^{5}$ copies of each target gene.

Triplex validation and application on clinical samples. As reference for HPV detection, we used the diagnostic results obtained at the IHU Méditerranée Infection laboratory using the Xpert HPV Assay (CEPHEID) from 96 clinical materials (67 cervico-vaginal smears, four vaginal swabs, one cervix, 19 anal smears, five rectal swabs) collected in liquid-based media (PreservCyt, HOLOGIC) (Supplementary Table 1). The Xpert HPV Assay is a real-time polymerase chain reaction assay using disposable cartridges that is able to detect 14 
types of high-risk HPV DNA (types $16,18,31,33,35,39,45,51,52,56,58,59,66,68$ ). Partial genotyping is provided for HPV16, HPV18 and/or 45, and HR-HPV other than 16, 18 or 45. The 96 clinical samples consisted in 43 HPV16 positive, 35 HPV18/45 positive, 3 HPV16 and HPV18/45 positive, seven positives for other HRHPVs and $8 \mathrm{HPV}$ negative.

For testing the multiplex systems developed in the present work, DNA extraction from $1 \mathrm{~mL}$ of each of the 96 original clinical samples was performed using the BioRobot EZ1 instrument (QIAGEN) or High Pure Nucleic Acid Large Volume extraction kits (ROCHE) according to the manufacturer recommendations. qPCR on DNA samples $(5 \mu \mathrm{L})$ were run on a CFX C1000 Touch (BIORAD) according to the optimized parameters determined in this work. $\mathrm{qPCR}$ products with $\mathrm{Ct}$ values $>38$ and PCR products visible on a $\%$ agarose gel using universal HPV primers were verified by Sanger sequencing using Big Dye Terminator v1.1 Cycle Sequencing Kit (LIFE TECHNOLOGIES) according to manufacturer recommendations on a 3500XL Genetic Analyzer capillary sequencer (THERMOFISHER).

Using the standard curve, the copy number of each HPV18/16 oncogenes and GAPDH was determined. The HPV viral load was calculated according to the following formula ${ }^{26}$ :

$$
\text { Viral load }\left(H P V \text { oncogene } \frac{\text { copies }}{10^{6} \text { cells }}\right)=\frac{\text { number of HPV oncogene copies }}{\text { number of GAPDH copies } / 2} \times 10^{6}
$$

Ethics statement. Clinical samples used in this study have been collected in the setting of routine standard clinical management and informed consent was obtained from all subjects. The study was approved by the ethical committee of the University Hospital Institute Méditerranée Infection (No. 2020-03). The study was performed according to the good clinical practices recommended by the Declaration of Helsinki (and its amendments) and all methods were carried out in accordance with relevant guidelines and regulations.

Statistical analyses. All statistical analyses were performed using the Prism 7 software (GRAPHPAD). Two-way ANOVA and Tukey's multiple comparison test were performed to analyze the differences between the $\mathrm{Ct}$ and RFU values (for primer and probe concentrations) between conditions, with H0 rejected for a p-value $<0.05$. Concordance and Cohen's kappa value ${ }^{33}$ were calculated to determine the level of agreement of HPV16 and HPV18 detection results between the multiplex systems developed in this study and the Xpert HPV Assay. Kappa values of $<0.20,0.21-0.40,0.41-0.60,0.61-0.80$ and $0.81-1.00$ were considered poor, fair, moderate, good and very good agreement, respectively.

\section{Results}

Optimization of the multiplex qPCR parameters. To optimize the fluorescence rate of each gene in the multiplex system, four primer concentrations ( $400 \mathrm{nM}, 600 \mathrm{nM}, 800 \mathrm{nM}, 1000 \mathrm{nM})$ and four probe concentrations $(50 \mathrm{nM}, 100 \mathrm{nM}, 150 \mathrm{nM}, 200 \mathrm{nM})$ were tested. The optimal concentration for the two multiplex qPCRs (HPV16 or HPV18) was determined as the highest relative fluorescence unit (RFU) for the lowest Ct value (Table 2a,b). Results showed that best RFU means were obtained with $200 \mathrm{nM}$ of probe $(\mathrm{p} \leq 0.05)$ and that there were no significant differences between $\mathrm{Ct}$ values and primer concentrations independently of probe concentration $(\mathrm{p}>0.05)$. The lowest concentration of primers $(400 \mathrm{nM})$ was then selected as optimal condition.

A temperature gradient $\left(54^{\circ} \mathrm{C}, 56.4^{\circ} \mathrm{C}, 57.8^{\circ} \mathrm{C}\right.$ and $\left.60^{\circ} \mathrm{C}\right)$ was tested to select the best annealing temperature for the lowest $\mathrm{Ct}$ value (Table $3 \mathrm{a}, \mathrm{b})$. For the two multiplex qPCRs, Ct values were not significantly different among all the temperatures tested $(\mathrm{p}>0.05)$. To be as specific as possible, we thus selected the annealing temperature of $60^{\circ} \mathrm{C}$ as optimal temperature.

Multiplex qPCR specificity. To determine the multiplex specificity for the two HPVs, each plasmid gene $(E 6, E 7, G A P D H)$ separately or pooled were run in qPCR reaction mixes with the pool of primers and probes for HPV 16 or HPV 18 using the optimal qPCR parameters previously determined. qPCR resulted in a single curve for each specific plasmid run in the HPV16 multiplex mix. This indicated that this triplex was able to detect all the three genes without cross-amplification and non-specific background fluorescence (Fig. 1a). For HPV18, non-specific background amplification of $E 6$ and $E 7$ and cross-amplification between HPV16 and HPV18 were observed after a Ct of 38 (Fig. 1b).

Sensitivity of the HPV multiplex qPCR. In the qPCR reactions, all standard curves showed a strong linear correlation (coefficient average $\mathrm{R}^{2}>0.9990$ ) for all tested genes (Fig. 2a-f). Amplification efficiencies for the HPV16 qPCR were $88.96 \%$ for E6, 91.76\% for E7 and 90.15\% for GAPDH (Fig. 2a-c). Amplification efficiencies for the HPV18 qPCR were $91.81 \%$ for $E 6,96.63 \%$ for $E 7$ and $93.03 \%$ for GAPDH (Fig. 2d-f). The regression curve slope was $-3.6183,-3.5365$ and -3.583 for the E6, E7 and GAPDH genes for the HPV16 triplex qPCR, respectively, and $-3.5353,-3.4054$ and -3.5011 for the E6, E7 and GAPDH genes of the HPV18 triplex qPCR, respectively.

Limits of detection (LOD) were determined as the last dilution of plasmids for which $\geq 95 \%$ of the intra- and inter-triplicates gave a positive result. The mean frequency of positives for the multiplex qPCR was $100 \%$ at $10^{2}$ plasmid copies/ $\mu \mathrm{L}$, and $97.88 \%$ and $97.34 \%$ at $10^{1}$ plasmid copies/ $\mu \mathrm{L}$ for HPV 16 and HPV 18 , respectively (Table 4).

Assay reproducibility. The coefficient of variations for the biological (intra-assay) triplicates were all less than $8 \%$ and those for the technical (inter-assay) triplicates were all less than 5\% (Tables 2 and 3 ). 


\begin{tabular}{|c|c|c|c|c|c|c|c|c|c|c|c|c|c|}
\hline \multirow[b]{3}{*}{$\begin{array}{l}\text { Probe } \\
\text { concentrations }\end{array}$} & \multirow[b]{3}{*}{$\begin{array}{l}\text { Primer } \\
\text { concentrations }\end{array}$} & \multicolumn{4}{|l|}{ E6 } & \multicolumn{4}{|l|}{ E7 } & \multicolumn{4}{|c|}{ GAPDH } \\
\hline & & \multicolumn{4}{|c|}{ Coefficient of variation } & \multicolumn{4}{|c|}{ Coefficient of variation } & \multicolumn{4}{|c|}{ Coefficient of variation } \\
\hline & & $\begin{array}{l}\mathrm{Ct} \\
\text { mean }^{\mathrm{a}}\end{array}$ & $\begin{array}{l}\text { RFUs } \\
\text { mean }\end{array}$ & Intra-assay & \begin{tabular}{|l} 
Inter- \\
assay \\
$(\%)$
\end{tabular} & $\begin{array}{l}\text { Ct } \\
\text { mean }^{\mathrm{a}}\end{array}$ & $\begin{array}{l}\text { RFUs } \\
\text { mean }\end{array}$ & Intra-assay & \begin{tabular}{|l} 
Inter- \\
assay \\
(\%)
\end{tabular} & $\begin{array}{l}\mathrm{Ct} \\
\text { mean }^{\mathrm{a}}\end{array}$ & $\begin{array}{l}\text { RFUs } \\
\text { mean }\end{array}$ & Intra-assay & $\begin{array}{l}\text { Inter- } \\
\text { assay } \\
(\%)\end{array}$ \\
\hline \multicolumn{14}{|l|}{ (a) HPV16 } \\
\hline \multirow{4}{*}{$50 \mathrm{nM}$} & $400 \mathrm{nM}$ & 24.13 & 809 & $0.05 \% \leq \mathrm{CV} \leq 1.7 \%$ & 0.24 & 23.31 & 417 & $0.94 \% \leq \mathrm{CV} \leq 1.81 \%$ & 0.84 & 22.05 & 265 & $0.47 \% \leq \mathrm{CV} \leq 1.82 \%$ & 1.30 \\
\hline & $600 \mathrm{nM}$ & 24.35 & 826 & $0.35 \% \leq \mathrm{CV} \leq 0.92 \%$ & 0.91 & 23.46 & 427 & $0.88 \% \leq \mathrm{CV} \leq 1.70 \%$ & 0.54 & 22.41 & 257 & $0.00 \% \leq \mathrm{CV} \leq 0.81 \%$ & 0.32 \\
\hline & $800 \mathrm{nM}$ & 24.44 & 823 & $0.83 \% \leq \mathrm{CV} \leq 0.97 \%$ & 0.70 & 23.42 & 433 & $1.34 \% \leq \mathrm{CV} \leq 3.34 \%$ & 1.39 & 22.47 & 260 & $0.55 \% \leq \mathrm{CV} \leq 1.36 \%$ & 1.15 \\
\hline & $1000 \mathrm{nM}$ & 24.41 & 823 & $0.24 \% \leq \mathrm{CV} \leq 0.42 \%$ & 0.81 & 23.52 & 430 & $0.39 \% \leq \mathrm{CV} \leq 3.17 \%$ & 0.63 & 22.48 & 254 & $0.27 \% \leq \mathrm{CV} \leq 0.52 \%$ & 0.08 \\
\hline \multirow{4}{*}{$100 \mathrm{nM}$} & $400 \mathrm{nM}$ & 24.11 & 1892 & $0.52 \% \leq \mathrm{CV} \leq 3.30 \%$ & 0.80 & 23.35 & 951 & $0.35 \% \leq \mathrm{CV} \leq 7.38 \%$ & 1.90 & 22.64 & 616 & $1.45 \% \leq \mathrm{CV} \leq 2.89 \%$ & 0.83 \\
\hline & $600 \mathrm{nM}$ & 24.27 & 1770 & $0.18 \% \leq \mathrm{CV} \leq 0.41 \%$ & 0.45 & 23.06 & 945 & $0.98 \% \leq \mathrm{CV} \leq 2.21 \%$ & 0.15 & 22.54 & 582 & $0.40 \% \leq \mathrm{CV} \leq 0.58 \%$ & 0.81 \\
\hline & $800 \mathrm{nM}$ & 24.35 & 1726 & $0.21 \% \leq \mathrm{CV} \leq 0.78 \%$ & 0.75 & 23.00 & 937 & $0.91 \% \leq \mathrm{CV} \leq 1.29 \%$ & 1.84 & 22.44 & 564 & $0.59 \% \leq \mathrm{CV} \leq 2.37 \%$ & 1.63 \\
\hline & $1000 \mathrm{nM}$ & 24.33 & 1731 & $0.24 \% \leq \mathrm{CV} \leq 0.84 \%$ & 0.55 & 23.02 & 927 & $1.11 \% \leq \mathrm{CV} \leq 1.54 \%$ & 0.06 & 22.51 & 555 & $0.34 \% \leq \mathrm{CV} \leq 1.53 \%$ & 1.04 \\
\hline \multirow{4}{*}{$150 \mathrm{nM}$} & $400 \mathrm{nM}$ & 24.19 & 2435 & $0.10 \% \leq \mathrm{CV} \leq 0.42 \%$ & 0.11 & 23.23 & 1311 & $1.58 \% \leq \mathrm{CV} \leq 1.79 \%$ & 1.63 & 22.50 & 827 & $0.54 \% \leq \mathrm{CV} \leq 0.90 \%$ & 1.20 \\
\hline & $600 \mathrm{nM}$ & 24.19 & 2465 & $0.25 \% \leq \mathrm{CV} \leq 0.66 \%$ & 0.26 & 23.23 & 1316 & $0.26 \% \leq \mathrm{CV} \leq 2.98 \%$ & 1.41 & 22.58 & 800 & $0.52 \% \leq \mathrm{CV} \leq 0.81 \%$ & 1.18 \\
\hline & $800 \mathrm{nM}$ & 24.37 & 2496 & $0.47 \% \leq \mathrm{CV} \leq 1.30 \%$ & 0.17 & 23.35 & 1340 & $0.86 \% \leq \mathrm{CV} \leq 1.60 \%$ & 1.58 & 22.43 & 807 & $0.41 \% \leq \mathrm{CV} \leq 1.62 \%$ & 2.90 \\
\hline & $1000 \mathrm{nM}$ & 24.28 & 2508 & $0.17 \% \leq \mathrm{CV} \leq 0.31 \%$ & 0.90 & 23.39 & 1341 & $0.17 \% \leq \mathrm{CV} \leq 1.79 \%$ & 1.99 & 22.63 & 799 & $0.15 \% \leq \mathrm{CV} \leq 0.59 \%$ & 1.51 \\
\hline \multirow{4}{*}{$200 \mathrm{nM}$} & $400 \mathrm{nM}$ & 24.29 & 3279 & $0.12 \% \leq \mathrm{CV} \leq 0.94 \%$ & 0.76 & 23.30 & 1747 & $0.25 \% \leq \mathrm{CV} \leq 2.07 \%$ & 0.63 & 22.93 & 1143 & $0.78 \% \leq \mathrm{CV} \leq 1.14 \%$ & 1.19 \\
\hline & $600 \mathrm{nM}$ & 24.35 & 3235 & $0.04 \% \leq \mathrm{CV} \leq 0.62 \%$ & 0.43 & 23.45 & 1694 & $0.42 \% \leq \mathrm{CV} \leq 4.02 \%$ & 0.90 & 22.79 & 1079 & $0.48 \% \leq \mathrm{CV} \leq 1.67 \%$ & 0.86 \\
\hline & $800 \mathrm{nM}$ & 24.33 & 3309 & $0.17 \% \leq \mathrm{CV} \leq 1.86 \%$ & 0.89 & 22.89 & 1832 & $0.37 \% \leq \mathrm{CV} \leq 3.18 \%$ & 3.28 & 22.52 & 1130 & $0.22 \% \leq \mathrm{CV} \leq 1.05 \%$ & 0.40 \\
\hline & $1000 \mathrm{nM}$ & 24.40 & 3156 & $0.25 \% \leq \mathrm{CV} \leq 0.54 \%$ & 0.30 & 23.04 & 1728 & $0.55 \% \leq \mathrm{CV} \leq 2.43 \%$ & 0.90 & 22.66 & 1052 & $0.17 \% \leq \mathrm{CV} \leq 2.22 \%$ & 2.01 \\
\hline \multicolumn{14}{|l|}{ (b) HPV 18} \\
\hline \multirow{4}{*}{$50 \mathrm{nM}$} & $400 \mathrm{nM}$ & 22.70 & 790 & $0.27 \% \leq \mathrm{CV} \leq 1.14 \%$ & 1.47 & 24.81 & 497 & $0.62 \% \leq \mathrm{CV} \leq 2.91 \%$ & 0.71 & 22.44 & 273 & $0.58 \% \leq \mathrm{CV} \leq 2.11 \%$ & 0.72 \\
\hline & $600 \mathrm{nM}$ & 22.85 & 848 & $0.65 \% \leq \mathrm{CV} \leq 1.13 \%$ & 1.13 & 24.77 & 510 & $0.20 \% \leq \mathrm{CV} \leq 2.29 \%$ & 0.91 & 22.60 & 256 & $0.20 \% \leq \mathrm{CV} \leq 1.89 \%$ & 1.01 \\
\hline & $800 \mathrm{nM}$ & 23.10 & 908 & $0.09 \% \leq \mathrm{CV} \leq 0.47 \%$ & 0.28 & 24.79 & 542 & $0.68 \% \leq \mathrm{CV} \leq 2.14 \%$ & 1.86 & 22.68 & 268 & $0.26 \% \leq \mathrm{CV} \leq 1.28 \%$ & 1.77 \\
\hline & $1000 \mathrm{nM}$ & 23.26 & 835 & $0.24 \% \leq \mathrm{CV} \leq 1.04 \%$ & 1.44 & 24.75 & 507 & $0.60 \% \leq \mathrm{CV} \leq 1.86 \%$ & 1.36 & 22.78 & 237 & $0.26 \% \leq \mathrm{CV} \leq 1.06 \%$ & 1.36 \\
\hline \multirow{4}{*}{$100 \mathrm{nM}$} & $400 \mathrm{nM}$ & 22.33 & 1768 & $0.56 \% \leq \mathrm{CV} \leq 1.74 \%$ & 3.17 & 24.83 & 1025 & $0.44 \% \leq \mathrm{CV} \leq 5.48 \%$ & 3.13 & 22.93 & 610 & $0.09 \% \leq \mathrm{CV} \leq 1.54 \%$ & 2.22 \\
\hline & $600 \mathrm{nM}$ & 22.79 & 1791 & $0.30 \% \leq \mathrm{CV} \leq 0.62 \%$ & 2.94 & 24.84 & 995 & $0.85 \% \leq \mathrm{CV} \leq 3.24 \%$ & 1.16 & 22.98 & 581 & $0.44 \% \leq \mathrm{CV} \leq 1.24 \%$ & 2.50 \\
\hline & $800 \mathrm{nM}$ & 22.74 & 1877 & $0.60 \% \leq \mathrm{CV} \leq 1.70 \%$ & 3.73 & 24.69 & 1016 & $0.53 \% \leq \mathrm{CV} \leq 0.69 \%$ & 1.38 & 22.90 & 582 & $0.31 \% \leq \mathrm{CV} \leq 1.70 \%$ & 3.32 \\
\hline & $1000 \mathrm{nM}$ & 22.97 & 1846 & $0.48 \% \leq \mathrm{CV} \leq 1.54 \%$ & 3.48 & 25.00 & 968 & $0.86 \% \leq \mathrm{CV} \leq 2.23 \%$ & 2.09 & 23.06 & 552 & $0.28 \% \leq \mathrm{CV} \leq 1.51 \%$ & 2.96 \\
\hline \multirow{4}{*}{$150 \mathrm{nM}$} & $400 \mathrm{nM}$ & 22.91 & 2115 & $0.39 \% \leq \mathrm{CV} \leq 1.30 \%$ & 1.06 & 24.81 & 1270 & $0.43 \% \leq \mathrm{CV} \leq 2.61 \%$ & 1.65 & 23.25 & 747 & $0.15 \% \leq \mathrm{CV} \leq 2.11 \%$ & 0.71 \\
\hline & $600 \mathrm{nM}$ & 23.18 & 2313 & $0.26 \% \leq \mathrm{CV} \leq 0.66 \%$ & 1.07 & 25.50 & 1265 & $1.19 \% \leq \mathrm{CV} \leq 7.30 \%$ & 1.82 & 23.32 & 730 & $0.45 \% \leq \mathrm{CV} \leq 1.00 \%$ & 0.89 \\
\hline & $800 \mathrm{nM}$ & 23.21 & 2366 & $0.29 \% \leq \mathrm{CV} \leq 1.82 \%$ & 0.56 & 24.90 & 1347 & $1.13 \% \leq \mathrm{CV} \leq 3.23 \%$ & 0.89 & 23.15 & 703 & $0.30 \% \leq \mathrm{CV} \leq 1.37 \%$ & 0.33 \\
\hline & $1000 \mathrm{nM}$ & 23.36 & 2485 & $0.20 \% \leq \mathrm{CV} \leq 1.35 \%$ & 0.99 & 25.10 & 1384 & $0.62 \% \leq \mathrm{CV} \leq 4.09 \%$ & 0.43 & 23.35 & 725 & $0.85 \% \leq \mathrm{CV} \leq 1.56 \%$ & 0.70 \\
\hline \multirow{4}{*}{$200 \mathrm{nM}$} & $400 \mathrm{nM}$ & 23.01 & 2948 & $0.24 \% \leq \mathrm{CV} \leq 1.09 \%$ & 0.98 & 25.15 & 1687 & $1.34 \% \leq \mathrm{CV} \leq 1.92 \%$ & 0.83 & 23.36 & 1107 & $0.28 \% \leq \mathrm{CV} \leq 0.64 \%$ & 0.96 \\
\hline & $600 \mathrm{nM}$ & 23.19 & 3298 & $0.33 \% \leq \mathrm{CV} \leq 0.61 \%$ & 0.64 & 25.45 & 1629 & $0.46 \% \leq \mathrm{CV} \leq 2.32 \%$ & 1.20 & 25.52 & 1075 & $0.20 \% \leq \mathrm{CV} \leq 0.94 \%$ & 1.15 \\
\hline & $800 \mathrm{nM}$ & 23.33 & 3499 & $0.28 \% \leq \mathrm{CV} \leq 0.60 \%$ & 0.76 & 24.96 & 1734 & $0.36 \% \leq \mathrm{CV} \leq 1.01 \%$ & 1.78 & 23.49 & 1084 & $0.64 \% \leq \mathrm{CV} \leq 0.88 \%$ & 0.15 \\
\hline & $1000 \mathrm{nM}$ & 23.51 & 3354 & $0.21 \% \leq \mathrm{CV} \leq 1.16 \%$ & 1.06 & 25.05 & 1702 & $0.98 \% \leq \mathrm{CV} \leq 1.18 \%$ & 1.69 & 23.65 & 1,000 & $0.14 \% \leq \mathrm{CV} \leq 0.87 \%$ & 0.58 \\
\hline
\end{tabular}

Table 2. Intra- and inter-assay reproducibility of HPV16 (a) and HPV18 (b) qPCR multiplexes for selected primer and probe concentrations. Ct cycle threshold. ${ }^{a}$ Mean of inter-assay Ct from technical triplicate.

Assay performance of HPV16 and HPV18 multiplex qPCR. Concordance between results from our in-house multiplex qPCR systems and from the Xpert HPV Assay was analyzed for 96 clinical samples (Supplementary Table 1). Among these samples, 46 were detected positive for HPV16 and 38 for HPV18/45 (including three samples positive for both HPV16 and HPV18/45). Negative controls consisted in seven other HR-HPVs and eight HPV-negative samples (Supplementary Table 1).

Among the 46 samples found HPV16-positive by the Xpert HPV Assay, 44 were also positive using the triplex qPCR developed in this study. For these samples, Ct of the GAPDH gene ranged between 21.07 and 38.48 (median 24.32). The E6 gene showed Ct values between 15.74 and 39.07 (median, 26.16) and the $E 7$ gene had a Ct range between 15.66 and 39.82 (median, 25.03). Seven samples presented Ct $>35$ for E6 or E7 genes. For 3/7, only the E6 gene was detected while for $1 / 7$ only E7 was detected. Co-infection with HPV18 was detected in 13 samples (e.g., samples no. 10, 31, 32, 36, 37, 40, 41, 43, 45, 47, 48, 64 and 90). For 2 samples (no. 47 and 48), the GAPDH gene was not detected whereas E6 and E7 oncogenes were early detected (Ct between 15.66 and 20.46). For one sample (no. 2), results were discordant between the Xpert HPV Assay and the multiplex qPCR developed here, as HPV18 was detected instead of HPV16.

Among the 38 HPV18/45 samples detected by the Xpert HPV Assay, 18 were found HPV18-positive using the triplex qPCR. Ct ranged between 21.19 and 30.45 (median, 24.66) for the GAPDH gene, between 15.18 and 38.90 (median, 30.32) for the E6 gene and between 16.45 and 39.60 (median, 32.90) for the E7 gene. Samples that 


\begin{tabular}{|c|c|c|c|c|c|c|c|c|c|c|c|c|}
\hline & \multicolumn{4}{|l|}{ E6 } & \multicolumn{4}{|l|}{ E7 } & \multicolumn{4}{|l|}{ GAPDH } \\
\hline & \multicolumn{4}{|c|}{\begin{tabular}{|l|} 
Coefficient of variation \\
\end{tabular}} & \multicolumn{4}{|c|}{ Coefficient of variation } & \multicolumn{4}{|c|}{ Coefficient of variation } \\
\hline & Ct mean ${ }^{\mathrm{a}}$ & \begin{tabular}{|l|} 
RFUs \\
mean
\end{tabular} & Intra-assay & $\begin{array}{l}\text { Inter- } \\
\text { assay }\end{array}$ & Ct mean ${ }^{\mathrm{a}}$ & $\begin{array}{l}\text { RFUs } \\
\text { mean }\end{array}$ & Intra-assay & \begin{tabular}{|l|} 
Inter- \\
assay
\end{tabular} & Ct mean ${ }^{a}$ & $\begin{array}{l}\text { RFUs } \\
\text { mean }\end{array}$ & Intra-assay & \begin{tabular}{|l|} 
Inter- \\
assay
\end{tabular} \\
\hline \multicolumn{13}{|c|}{ (a) HPV 16} \\
\hline $\operatorname{Tm} 60^{\circ} \mathrm{C}$ & 26.65 & 1999 & $0.61 \% \leq \mathrm{CV} \leq 1.99 \%$ & $2.12 \%$ & 25.69 & 1674 & $0.46 \% \leq \mathrm{CV} \leq 1.78 \%$ & $2.67 \%$ & 26.47 & 1065 & $0.53 \% \leq \mathrm{CV} \leq 1.29 \%$ & $0.46 \%$ \\
\hline $\begin{array}{l}\mathrm{Tm} \\
57.8^{\circ} \mathrm{C}\end{array}$ & 26.66 & 1523 & $0.75 \% \leq \mathrm{CV} \leq 3.03 \%$ & $0.80 \%$ & 25.02 & 1844 & $0.67 \% \leq \mathrm{CV} \leq 2.85 \%$ & $1.60 \%$ & 26.60 & 1071 & $0.38 \% \leq \mathrm{CV} \leq 0.85 \%$ & $0.38 \%$ \\
\hline $\begin{array}{l}\mathrm{Tm} \\
56.4^{\circ} \mathrm{C}\end{array}$ & 26.50 & 1230 & $0.91 \% \leq \mathrm{CV} \leq 2.38 \%$ & $1.42 \%$ & 25.24 & 1854 & $1.66 \% \leq \mathrm{CV} \leq 2.82 \%$ & $2.09 \%$ & 26.53 & 1115 & $0.47 \% \leq \mathrm{CV} \leq 2.55 \%$ & $0.72 \%$ \\
\hline $\operatorname{Tm} 54^{\circ} \mathrm{C}$ & 26.60 & 1064 & $1.10 \% \leq \mathrm{CV} \leq 3.17 \%$ & $1.91 \%$ & 25.43 & 1747 & $1.78 \% \leq \mathrm{CV} \leq 3.45 \%$ & $2.97 \%$ & 26.58 & 1026 & $0.49 \% \leq \mathrm{CV} \leq 2.05 \%$ & $0.83 \%$ \\
\hline \multicolumn{13}{|c|}{ (b) HPV 18} \\
\hline $\operatorname{Tm} 60^{\circ} \mathrm{C}$ & 24.00 & 3180 & $0.07 \% \leq \mathrm{CV} \leq 1.57 \%$ & 3.12 & 26.63 & 1549 & $1.17 \% \leq \mathrm{CV} \leq 2.92 \%$ & $5.05 \%$ & 24.59 & 1314 & $1.22 \% \leq \mathrm{CV} \leq 3.12 \%$ & $3.63 \%$ \\
\hline $\begin{array}{l}\mathrm{Tm} \\
57.8^{\circ} \mathrm{C}\end{array}$ & 24.74 & 2488 & $0.47 \% \leq \mathrm{CV} \leq 1.65 \%$ & 1.76 & 27.19 & 1385 & $0.25 \% \leq \mathrm{CV} \leq 2.03 \%$ & $0.92 \%$ & 25.08 & 1048 & $0.28 \% \leq \mathrm{CV} \leq 1.22 \%$ & $2.09 \%$ \\
\hline $\begin{array}{l}\mathrm{Tm} \\
56.4^{\circ} \mathrm{C}\end{array}$ & 24.53 & 2613 & $0.44 \% \leq \mathrm{CV} \leq 1.01 \%$ & 1.80 & 27.13 & 1455 & $0.56 \% \leq \mathrm{CV} \leq 1.85 \%$ & $4.36 \%$ & 24.97 & 1073 & $0.52 \% \leq \mathrm{CV} \leq 1.16 \%$ & $1.55 \%$ \\
\hline $\operatorname{Tm} 54^{\circ} \mathrm{C}$ & 25.15 & 2760 & $0.82 \% \leq \mathrm{CV} \leq 1.02 \%$ & 4.56 & 27.31 & 1506 & $0.86 \% \leq \mathrm{CV} \leq 2.05 \%$ & $3.12 \%$ & 25.92 & 1081 & $0.80 \% \leq \mathrm{CV} \leq 2.03 \%$ & $3.73 \%$ \\
\hline
\end{tabular}

Table 3. Intra- and inter-assay reproducibility of HPV16 (a) and HPV18 (b) qPCR multiplexes for selected annealing temperatures. $C t$ cycle threshold, $C v$ coefficient of variation. ${ }^{a}$ Mean of inter-assay Ct of technical triplicate.
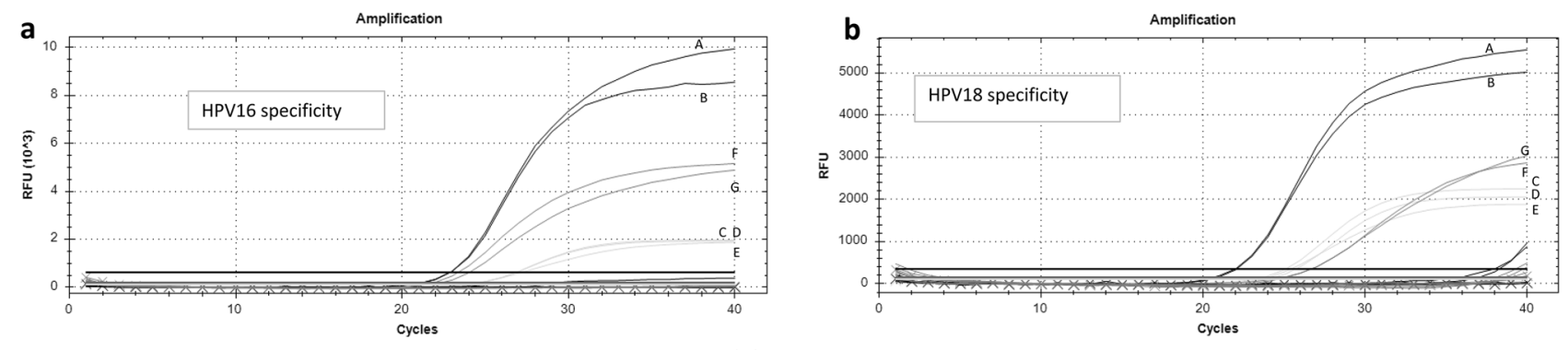

$\nVdash X X$ Negative control
- FAM fluorescent dye (E6-gene)
VIC fluorescent dye (E7-gene)
CY5 fluorescent dye (GAPDH-gene

Figure 1. Amplification patterns obtained with the multiplex systems on plasmid DNA. The curves were generated by amplification of $10^{5}$ copies of plasmid/2 $\mu \mathrm{L}$ of single or pooled $E 6, E 7$ and/or GAPDH plasmid for HPV16 and HPV18. (a) Specificity of HPV16 E6, E7 and GAPDH multiplex for the detection of HPV16 plasmid pool (A, E, G), HPV16 E6 plasmid (B), GAPDH plasmid (C), HPV16 E7 plasmid (F) and HPV18 plasmid pool (D) (b) Specificity of HPV18 E6, E7 and GAPDH multiplex for the detection of HPV18 plasmid pool (B, E, G), HPV18 E6 plasmid (A), GAPDH plasmid (C), HPV18 E7 plasmid (F), HPV16 plasmid pool (D).

were HPV18-negative were expected to be HPV45 and were verified by Sanger sequencing after conventional PCR using universal HPV primers ${ }^{34}$. The results confirmed HPV45 in seven cases, but also detected HPV53 in three cases. Co-infection with HPV16 was detected for three samples (no. 58, 64 and 90).

All negative samples $(n=8)$ were found negative, except one (sample no. 5), for which HPV16 and HPV18 coinfections were detected with late Ct values for E7 gene, 38.02 and 36.67, respectively. HPV16 was also detected in one of the other HR-HPV samples (no. 24).

Considering the negative controls (negative samples and other HR-HPVs) and the positive samples, the concordance between the Xpert HPV Assay and the triplex qPCRs developed in this study was 93.44\% for HPV 16 with a Cohen's kappa value of 0.82 (almost perfect agreement between the two tests) and $73.58 \%$ for HPV 18 with a Cohen's kappa value of 0.48 (moderate agreement).

In addition, for some clinical samples (e.g., samples no. 1, 3, 31, 39, 40, 43, 49, 58, 85), E6 and E7 oncogenes for both HPV18 and HPV16 were detected with at least $3 \mathrm{Ct}$ earlier than the GAPDH gene (Supplementary Table 1 and Supplementary Fig. 1a,b).

Using the standard curves of each gene of interest, the viral load of HPV copies $/ 10^{6}$ cells was determined (Supplementary Table 1). Viral load ranged from $3.52 \times 10^{1}$ to $2.78 \times 10^{8} \mathrm{HPV}$ copies $/ 10^{6}$ cells $\left( \pm \mathrm{SD}, 4.23 \times 10^{7}\right)$ for HPV 16 and from $4.12 \times 10^{1}$ to $7.87 \times 10^{8} \mathrm{HPV}$ copies $/ 10^{6}\left( \pm \mathrm{SD}, 1.48 \times 10^{8}\right)$ for HPV18. Some samples, particularly those from cervico-vaginal smears, presented a mean value close to the limit of detection previously defined at $10^{1}$ plasmid copy/ $\mu \mathrm{L}$ (e.g., sample no. 29 and 41 for HPV16 and sample no. 90 for HPV18). 


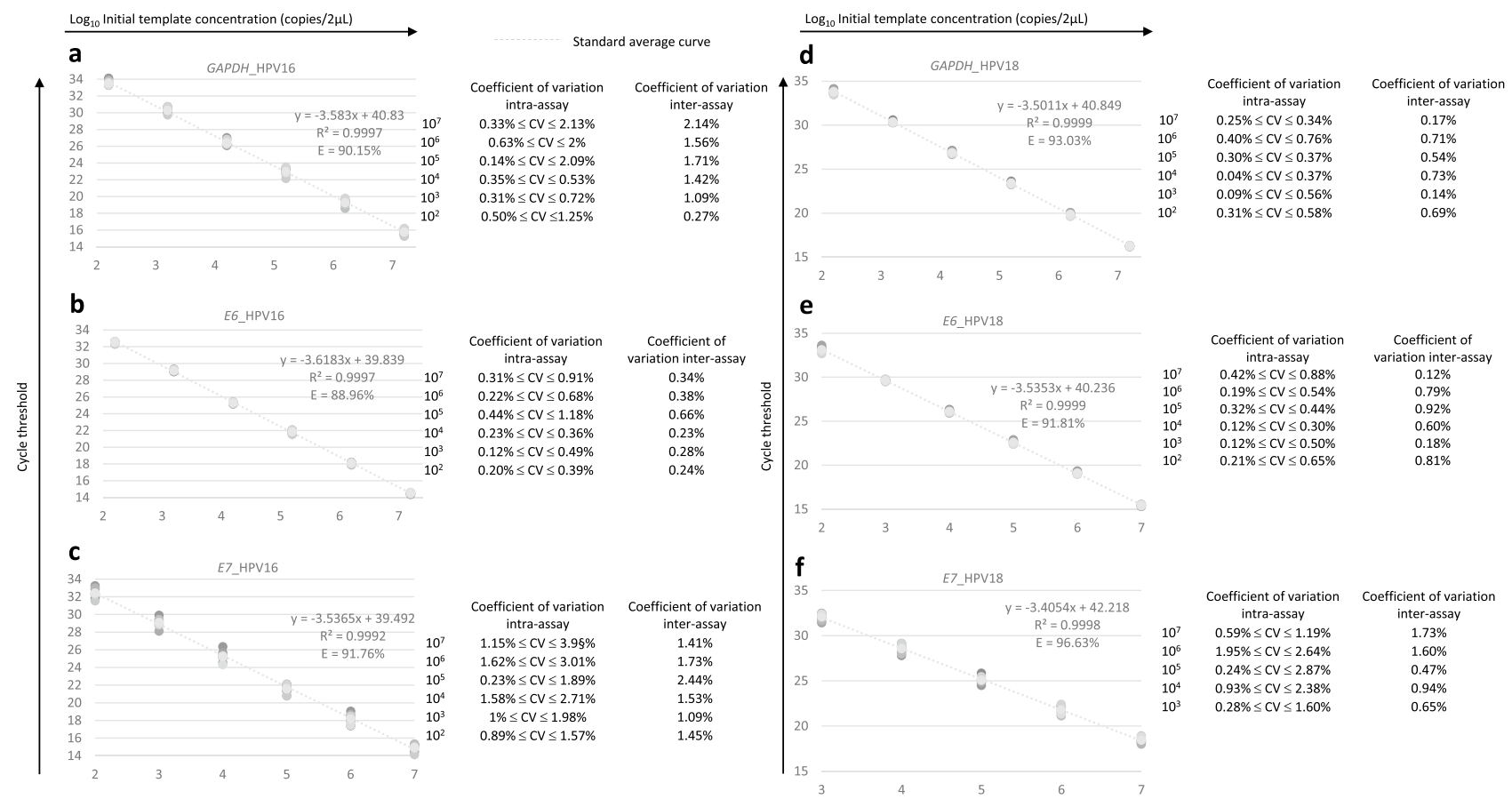

Figure 2. Sensibility and linearity of HPV16 and HPV18 triplexes. Standard curves were generated by amplification of serial dilutions from $10^{7}$ to $10^{-2}$ of E6, E7 and GAPDH plasmid pool for HPV16 (a-c) and HPV18 (d-f) using multiplex qPCR. Each dilution was run in biological and technical triplicate. $\mathrm{R}^{2}$ represent the coefficient of determination and the PCR efficiency (E) of each target was calculated using the slope of each standard curve with the formula $\mathrm{E}=\left(10^{-1 / \text { slope }}-1\right)^{\star} 100$.

\begin{tabular}{|l|l|l|l|l|l|l|l|l|l|}
\hline & $10^{\mathbf{0}}(\%)$ & $10^{\mathbf{1}}(\%)$ & $10^{2}(\%)$ & $10^{3}(\%)$ & $10^{4}(\%)$ & $10^{5}(\%)$ & $10^{6}(\%)$ & $10^{7}(\%)$ \\
\hline (a) HPV16 concentration (copy/ $\mathbf{\mu L})$ \\
\hline GAPDH & 83.3 & 93.65 & 100 & 100 & 100 & 100 & 100 & 100 \\
\hline E6 & 91.67 & 100 & 100 & 100 & 100 & 100 & 100 & 100 \\
\hline E7 & 91.67 & 100 & 100 & 100 & 100 & 100 & 100 & 100 \\
\hline Mean frequency of positive & 88.88 & 97.88 & 100 & 100 & 100 & 100 & 100 & 100 \\
\hline (b) HPV18 concentration (copy/ $\mathbf{L})$ \\
\hline GAPDH & 91.67 & 98.4 & 100 & 100 & 100 & 100 & 100 & 100 \\
\hline E6 & 93.06 & 98.4 & 100 & 100 & 100 & 100 & 100 & 100 \\
\hline E7 & 83.33 & 95.24 & 100 & 100 & 100 & 100 & 100 & 100 \\
\hline Mean frequency of positive & 89.35 & 97.34 & 100 & 100 & 100 & 100 & 100 & 100 \\
\hline
\end{tabular}

Table 4. Positive frequency for multiplex with plasmid serial dilution $\left(10^{7}-10^{0}\right.$ copies $\left./ \mu \mathrm{L}\right)$. Positive frequency was calculated according to the ratio between the numbers of positive amplification detection and the number of expected amplification curve for each dilution of HPV16 (a) and HPV18 (b).

\section{Discussion}

In most of cases (80-90\%), HPV infections are transient as the result of viral clearance by the host immune system whereas viral persistence is necessary to induce HPV related-diseases (warts, cancers...) ) $^{35,36}$. Between 60 and $90 \%$ of worldwide HPV cancers cases are due to HPV16 and/or HPV $18^{6}$ and infection by one of those HPV types has a predictive value of cervical intraepithelial neoplasia grade 3 lesion ${ }^{37}$. The present study describes the development and validation of two real-time PCR triplexes for fast detection and relative quantification of E6 and E7 DNA oncogenes for HPV16 and HPV 18.

Amplification efficiencies of each gene of the two multiplex systems ranged between 80 and $120 \%$ with good standard curve coefficient of correlation $\left(R^{2}>0.99\right)$. The difference between the PCR efficiencies obtained for each target gene of the multiplex system never exceeded 15\%, which further demonstrated the absence of competition between the different targets ${ }^{32,38}$. The low coefficient of variation for both intra- $(\leq 7.4 \%)$ and inter- $(\leq 3.7 \%)$ assays showed a good reproducibility of each steps of the multiplex development. The triplex qPCR assays allowed the detection of up to $10^{1}$ plasmid copies/ $\mu \mathrm{L}$ for all genes tested.

Currently, diagnosis of HPV infection often uses commercially available tests that target the complete genome, L1 gene or E6/E7 genes of a panel of HPV types (Hybrid Capture 2, Cervista HPV HR or HPV 16/18, Cobas 
HPV or Xpert HPV) ${ }^{39}$. Some of these qualitative HPV tests uses specific technologies such as hybrid capture with signal amplification by chemiluminescence (Hybrid Capture 2, Care HPV) or hybridization by FRET probe (Cervista HPV HR). Other HPV tests are easier to use but need specific additional laboratory equipment (Cobas HPV, Xpert HPV, Papillocheck). The two multiplex systems developed in this study allow detecting DNA of two of the most prevalent HR-HPVs and to quantify E6 and E7 oncogenes DNA levels compare to GAPDH housekeeping gene within the same amplification reaction. Moreover, in house probe-based real-time qPCR is a fast, easy to use, specific and reproducible method that only requires a minimal amount of DNA, does not need specific, assay-dedicated laboratory instrument, and can allow testing in the same run multiple sample DNA extracts on 96- or 384-well plates.

The multiplexes developed in this study confirmed the clinical diagnosis of the Xpert HPV assay with a concordance of $93.44 \%$ for HPV16 and $73.58 \%$ for HPV18. Lower concordance and Cohen's kappa value were observed for HPV18 as the Xpert HPV assay provided a positive signal for both HPV18 and HPV45 whereas our system only targeted HPV18. Using HPV DNA quantification, we noted for some patients that oncogenes $E 6$ and $E 7$ have a Ct value lower than the GAPDH gene. This could be a signature of an active virus replication and transient infection. In contrast, patients with $\mathrm{Ct}$ for oncogenes equal to or higher than the GAPDH gene may reflect persistence under an episomal state or HPV integration to the human genome. In this work, 15 samples with HPV18 and HPV16 co-infections were detected. Detection of HPV co-infections is of particular interest as a combination of HPV16/18 co-infection has been associated with grade 2 and 3 cervical intraepithelial neoplasia $(\mathrm{CIN})^{40}$. Viral loads per millions of human cells were determined for HPV16 and HPV18 as these could be a marker of CIN2 and be a predictor of lesion progression ${ }^{27,41,42}$. The value measured in this study were within the limits of the standard curves and showed large variations across patients and samples.

In 2010, a study showed that mRNA levels of E6 and E7 oncogenes are correlated with the severity of cervical intraepithelial neoplasia ${ }^{28}$. Quantification of mRNA could thus be a novel marker of HPV infection and cervical intraepithelial neoplasia progression ${ }^{43}$. So far, only few HPV detection test target mRNAs. These tests are qualitative (HPV-Proofer) and do not discriminate HPV types (Aptima HPV Assay). In 2018, a multiplex reverse transcription real-time PCR for E6/E7 mRNA detection of $14 \mathrm{~h}-\mathrm{HPV}$ without discrimination among types was developed ${ }^{44}$. This study confirmed the association of E6/E7 mRNA increased levels with the severity of the cervical lesions. Another study showed that the detection of both E6 and E7 mRNAs showed significant association with the occurrence of upgraded abnormal cytology ${ }^{45}$. In this study, we could simultaneously detect and quantify $E 6$ and $E 7$ genes within the same amplification reaction. The triplex qPCR developed in this study could then be used to assess E6/E7 oncogene mRNA levels for a personalized follow-up of patients with confirmed HPV 18 and/or HPV16 persistent infections, in order to survey women at risk of developing cervical carcinoma.

To conclude, the multiplex PCR systems developed in this study could be used as extra support of traditional HPV tests to validate specifically the presence of and quantify per million cells HPV16 and/or HPV18 DNA. It may also be used for research in second intention for the follow-up of patients with confirmed infection who are at risk of developing lesions by quantifying expression levels of E6 and E7 oncogenes normalized on the GAPDH expression. This could be easily realized simultaneously on many samples (96-384 wells qPCR plate) and could be developed in the future for other less frequent HR-HPVs.

Received: 5 October 2020; Accepted: 15 January 2021

Published online: 17 February 2021

\section{References}

1. Doorbar, J., Egawa, N., Griffin, H., Kranjec, C. \& Murakami, I. Human papillomavirus molecular biology and disease association. Rev. Med. Virol. 25, 2-23 (2015).

2. Burk, R. D., Chen, Z. \& Doorslaer, K. V. Human papillomaviruses: Genetic basis of carcinogenicity. Public Health Genom. 12, 281-290 (2009).

3. de Villiers, E.-M., Fauquet, C., Broker, T. R., Bernard, H.-U. \& zur Hausen, H. Classification of papillomaviruses. Virology 324, $17-27$ (2004).

4. Hutter, J. N. \& Decker, C. F. Human papillomavirus infection. Dis. Mon. https://doi.org/10.1016/j.disamonth.2016.03.014 (2016).

5. Viens, L. J. Human papillomavirus-associated cancers-United States, 2008-2012. MMWR Morb. Mortal. Wkly. Rep. 65, 661-666 (2016).

6. de Martel, C., Plummer, M., Vignat, J. \& Franceschi, S. Worldwide burden of cancer attributable to HPV by site, country and HPV type. Int. J. Cancer 141, 664-670 (2017).

7. Koshiol, J. et al. Persistent human papillomavirus infection and cervical neoplasia: A systematic review and meta-analysis. Am. J. Epidemiol. 168, 123-137 (2008).

8. WHO|Cervical cancer. Human Papillomavirus (HPV) and Cervical Cancer. World Health Organization. https://www.who.int/ news-room/fact-sheets/detail/human-papillomavirus-(hpv)-and-cervical-cancer (2020).

9. Lie, A. K. \& Kristensen, G. Human papillomavirus E6/E7 mRNA testing as a predictive marker for cervical carcinoma. Expert Rev. Mol. Diagn. 8, 405-415 (2008).

10. Oyervides-Muñoz, M. A. et al. Understanding the HPV integration and its progression to cervical cancer. Infect. Genet. Evolut. 61, 134-144 (2018).

11. Woodman, C. B. J., Collins, S. I. \& Young, L. S. The natural history of cervical HPV infection: Unresolved issues. Nat. Rev. Cancer 7, 11-22 (2007).

12. Werness, B. A., Levine, A. J. \& Howley, P. M. Association of human papillomavirus types 16 and 18 E6 proteins with p53. Science 248, 76-79 (1990).

13. Dyson, N., Guida, P., Münger, K. \& Harlow, E. Homologous sequences in adenovirus E1A and human papillomavirus E7 proteins mediate interaction with the same set of cellular proteins. J. Virol. 66, 6893-6902 (1992).

14. Katzenellenbogen, R. Telomerase induction in HPV infection and oncogenesis. Viruses 9, 180 (2017).

15. Crook, T., Vousden, K. H. \& Tidy, J. A. Degradation of p53 can be targeted by HPV E6 sequences distinct from those required for p53 binding and trans-activation. Cell 67, 547-556 (1991). 
16. Mahmoodi, P. et al. Early detection of cervical cancer based on high-risk HPV DNA-based genosensors: A systematic review. BioFactors 45, 101-117 (2019).

17. Shah, S. S. et al. Current technologies and recent developments for screening of HPV-associated cervical and oropharyngeal cancers. Cancers 8, 85 (2016).

18. Karsa, V. L. et al. European Guidelines for Quality Assurance in Cervical Cancer Screening: Supplements 2nd edn. (2015).

19. Australian Institute of Health and Welfare. Cervical Screening in Australia 2018 (Aust. Inst. Health Welf., Canberra, 2018).

20. Dépistage du cancer du col de l'utérus: le test HPV recommandé chez les femmes de plus de 30 ans. Haute Autorité de Santé. https ://www.has-sante.fr/jcms/p_3192618/fr/depistage-du-cancer-du-col-de-l-uterus-le-test-hpv-recommande-chez-les-femmes-deplus-de-30-ans (2020).

21. Nazarenko, I. et al. A novel method of HPV genotyping using Hybrid Capture sample preparation method combined with GP5+/6+ PCR and multiplex detection on Luminex XMAP. J. Virol. Methods 154, 76-81 (2008).

22. Day, S. P. et al. Analytical performance of the Investigational Use Only Cervista HPV HR test as determined by a multi-center study. J. Clin. Virol. Off. Publ. Pan Am. Soc. Clin. Virol. 45(Suppl 1), S63-72 (2009).

23. Bartholomew, D. A., Luff, R. D., Quigley, N. B., Curtis, M. \& Olson, M. C. Analytical performance of Cervista HPV 16/18 genotyping test for cervical cytology samples. J. Clin. Virol. Off. Publ. Pan Am. Soc. Clin. Virol. 51, 38-43 (2011).

24. Ying, H., Jing, F., Fanghui, Z., Youlin, Q. \& Yali, H. High-risk HPV nucleic acid detection kit-the careHPV test-A new detection method for screening. Sci. Rep. 4, 4704 (2014).

25. Rao, A. et al. Development and characterization of the cobas human papillomavirus test. J. Clin. Microbiol. 51, 1478-1484 (2013).

26. Carcopino, X. et al. Determination of HPV type 16 and 18 viral load in cervical smears of women referred to colposcopy. J. Med. Virol. 78, 1131-1140 (2006).

27. Xi, L. F. et al. Viral load in the natural history of human papillomavirus type 16 infection: A nested case-control study. J. Infect. Dis. 203, 1425-1433 (2011).

28. Ho, C.-M. et al. Type-specific human papillomavirus oncogene messenger RNA levels correlate with the severity of cervical neoplasia. Int. J. Cancer 127, 622-632 (2010).

29. Molden, T., Kraus, I., Skomedal, H., Nordstrøm, T. \& Karlsen, F. PreTect HPV-Proofer: real-time detection and typing of E6/E7 mRNA from carcinogenic human papillomaviruses. J. Virol. Methods 142, 204-212 (2007).

30. Dockter, J. et al. Analytical characterization of the APTIMA HPV Assay. J. Clin. Virol. Off. Publ. Pan Am. Soc. Clin. Virol. 45(Suppl 1), $539-47$ (2009).

31. He, Q. et al. circ-SHKBP1 regulates the angiogenesis of U87 glioma-exposed endothelial cells through miR-544a/FOXP1 and miR-379/FOXP2 pathways. Mol. Ther. Nucleic Acids 10, 331-348 (2017).

32. Broeders, S. et al. Guidelines for validation of qualitative real-time PCR methods. Trends Food Sci. Technol. 37, 115-126 (2014).

33. Altman, D. G. Practical Statistics for Medical Research (CRC Press, London, 1990).

34. Cossellu, G. et al. Prevalence and concordance of oral and genital HPV in women positive for cervical HPV infection and in their sexual stable partners: an Italian screening study. PLoS ONE 13, e0205574 (2018).

35. Miranda, P. M. et al. Persistence or clearance of human papillomavirus infections in women in Ouro Preto, Brazil. BioMed. Res. Int. https://doi.org/10.1155/2013/578276 (2013).

36. Stanley, M. Immunobiology of HPV and HPV vaccines. Gynecol. Oncol. 109, S15-S21 (2008).

37. Castle, P. E. et al. Performance of carcinogenic human papillomavirus (HPV) testing and HPV16 or HPV18 genotyping for cervical cancer screening of women aged 25 years and older: A subanalysis of the ATHENA study. Lancet Oncol. 12, 880-890 (2011).

38. Huber, I. et al. Development and validation of duplex, triplex, and pentaplex real-time PCR screening assays for the detection of genetically modified organisms in food and feed. J. Agric. Food Chem. 61, 10293-10301 (2013).

39. Abreu, A. L. P., Souza, R. P., Gimenes, F. \& Consolaro, M. E. L. A review of methods for detect human Papillomavirus infection. Virol. J. 9, 262 (2012).

40. Bruno, M. T., Scalia, G., Cassaro, N. \& Boemi, S. Multiple HPV 16 infection with two strains: A possible marker of neoplastic progression. BMC Cancer 20, 444 (2020).

41. Dalstein, V. et al. Persistence and load of high-risk HPV are predictors for development of high-grade cervical lesions: A longitudinal French cohort study. Int. J. Cancer 106, 396-403 (2003).

42. Josefsson, A. M. et al. Viral load of human papilloma virus 16 as a determinant for development of cervical carcinoma in situ: A nested case-control study. Lancet Lond. Engl. 355, 2189-2193 (2000).

43. Wentzensen, N. \& von Knebel Doeberitz, M. Biomarkers in cervical cancer screening. Dis. Markers 23, 315-330 (2007).

44. Pan, C., Zhou, J., Lyu, J. \& Ren, X. Development and validation of a multiplex reverse transcript real-time PCR for E6/E7 mRNA detection of high-risk human papillomavirus. J. Med. Microbiol. 67, 1509-1514 (2018).

45. Liu, S. et al. Separate analysis of human papillomavirus E6 and E7 messenger RNAs to predict cervical neoplasia progression. PLoS ONE 13, e0193061 (2018).

\section{Author contributions}

A.B. conducted experiments, analyzed data, and wrote the paper. C.D. designed research, analyzed data and revised all versions of the article. H.T.D. conducted patient consultations and collected the clinical specimens. A.M. contributed to samples screening from the diagnosis laboratory. P.C. contributed to samples screening from the diagnosis laboratory and revised the article. All authors revised and approved the final version.

\section{Funding}

This work was supported by the French Government under the "Investissements d'avenir" (Investments for the Future) program managed by the Agence Nationale de la Recherche (ANR, fr: National Agency for Research), no. 10-IAHU-03. This work was supported by Région Provence Alpes Côte d’Azur and European funding FEDER PRIMI.

\section{Competing interests}

The authors declare no competing interests.

\section{Additional information}

Supplementary Information The online version contains supplementary material available at https://doi. org/10.1038/s41598-021-83489-2.

Correspondence and requests for materials should be addressed to C.D.

Reprints and permissions information is available at www.nature.com/reprints. 
Publisher's note Springer Nature remains neutral with regard to jurisdictional claims in published maps and institutional affiliations.

(c) (i) Open Access This article is licensed under a Creative Commons Attribution 4.0 International License, which permits use, sharing, adaptation, distribution and reproduction in any medium or format, as long as you give appropriate credit to the original author(s) and the source, provide a link to the Creative Commons licence, and indicate if changes were made. The images or other third party material in this article are included in the article's Creative Commons licence, unless indicated otherwise in a credit line to the material. If material is not included in the article's Creative Commons licence and your intended use is not permitted by statutory regulation or exceeds the permitted use, you will need to obtain permission directly from the copyright holder. To view a copy of this licence, visit http://creativecommons.org/licenses/by/4.0/.

(C) The Author(s) 2021 